AIDA RAIO $(*)\left({ }^{\circ}\right)$ - PIO FEDERICO ROVERSI $(* *)$ - VALERIA FRANCARDI $(* *)$

\title{
BACTERIA ASSOCIATED TO RHYNCHOPHORUS FERRUGINEUS (OLIVIER) (COLEOPTERA DRYOPHTHORIDAE) IN ITALY
}

\author{
(*) Istituto per la Protezione Sostenibile delle Piante, CNR. Via Madonna del Piano, 10. 50019 Sesto Fiorentino (FI), \\ Italy. \\ (**) CREA-ABP, Research Centre for Agrobiology and Pedology, via Lanciola 12/A, Cascine del Riccio, 50125 Florence, \\ Italy \\ $\left({ }^{\circ}\right)$ Corresponding author: aida.raio@ipsp.cnr.it
}

\begin{abstract}
Raio A., Roversi P.F., Francardi V. - Bacteria associated to Rhynchophorus ferrugineus (Olivier) (Coleoptera Dryophthoridae) in Italy.

Thirty-five bacterial strains were selected on the basis of colony morphology from larvae and pupae of Rhynchophorous (Olivier) ferrugineus collected from infested Phoenix canariensis Chabaud trees growing in different Italian locations. 16S rDNA sequencing showed that bacteria isolated from larvae were mostly Gram positive and belonged to Bacillus, Brevibacillus and Paenibacillus genera. Bacteria isolated from pupae were affiliated to Bacillus and five different Gram negative genera (Alcaligenes, Morganella, Myroides, Providencia and Serratia). Some strains produced lytic enzymes like chitinase, lecithinase, lipase and protease in vitro. The enthomopathogenic strains belonging to Bacillus thuringiensis, Providencia rettgeri and Serratia marcescens species may be considered of interest as potential biocontrol agents of $R$. ferrugineus.
\end{abstract}

KeY Words: Phoenix canariensis, Red Palm Weevil, entomopathogenic bacteria, Providencia rettgeri, biocontrol.

\section{INTRODUCTION}

Rhynchophorous. ferrugineus (Olivier) is an exotic invasive insect pest that in a very short time, spread rapidly in Italy with devastating effects on ornamental palms. In the last 16 years it caused the death of thousands Phoenix canariensis Chabaud plants mainly in the Central-Southern Italian regions and in Sicily and Sardinia islands. Notwithstanding the species has been subjected to all the authorized control measures to remove dead plants and to treat promptly the attacked ones with chemical insecticides in order to save the palms and to prevent insect pest spread, the insect is still being in expansion in the Country. Palm trees are ubicated mainly in urban parks and boulevards within residential areas, where the use of chemicals elicits serious concerns related to environmental pollution and human health, consequently, eco-friendly biological control methods has now attracted high interests (MAZZA et al., 2014). Previous studies have demonstrated that spore-forming bacteria belonging to Bacillus genus (SAlAma et al., 2004) and the gram negative bacterium Pseudomonas aeruginosa caused the mortality of the larvae under standard biassay conditions (BANERJEE and DANGAR, 1995). As part of research carried out to develop low environmental impact control methods, several natural enemies and entomopathogenic microorganisms of $R$. ferrugineus have been evaluated (FRANCARDI et al., 2012; 2013a; 2013b; 2014; MAZZA et al., 2013, 2014; Ciто et al., 2014). but at present, no effective biocontrol agent is utilized currently.

In Italy, during a two year study (2012-2013) on the natural antagonist complex of $R$. ferrugineus, two important groups of entomopathogens belonging to fungi (Beauveria bassiana (Bals.-Criv.) Vuill. and Metarhizium anisopliae (Metschnikoff) Sorokin and bacteria, which caused the death of $15.74 \%$ and $11.88 \%$ of larvae and adults respectively (FRANCARDI et al., 2014), were identified. In the present paper the Authors focused the attention on the characterization of bacterial microflora associated to larvae and pupae of $R$. ferrugineus with the aim to evaluate potential biocontrol strains.

\section{MATERIAL AND METHODS}

\section{ISOLATION OF BACTERIA}

Cocoons and dead medium-large larvae (from $2 \mathrm{~cm}$ to 4-5 cm long) of $R$. ferrugineus were obtained from $P$. canariensis infested palms grown as ornamental in different urban areas of Sicily (Provinces of Catania, Ragusa, Agrigento and Enna) and Tuscany (Province of Lucca) regions. Samples were collected during felling operations of heavily attacked plants carried out by the local Plant Protection Services in order to contain the spread of the pest. $R$. ferrugineus larvae and cocoons with pupae inside were transferred in CREA-ABP laboratory in a quarantine room and examined; specimens with suspected symptoms of bacterial attacks were separated and treated to isolate the pathogen/s.

Larvae and pupae were surface sterilized in $70 \%$ ethanol for 5 minutes and then washed thoroughly with sterile distilled water three times. Each sample was cut in small pieces with a sterile scalpel and put in flasks containing 50 $\mathrm{ml}$ of Nutrient Broth (Oxoid) amended with $0,25 \%$ glucose (NGB). Flasks were incubated at $30^{\circ} \mathrm{C}$ for 48 hours on a rotary shaker. Samples were then serially diluted and aliquots of $100 \mu \mathrm{l}$ were spread on plates containing the medium previously indicated amended with agar (NGA) and Tryptic Soy Agar medium (Fluka). Twenty microliters of the undiluted samples were also 
streaked on the same agar media. Plates were incubated at $30^{\circ} \mathrm{C}$ for 48 hours. Bacterial isolates were selected on the basis of colony morphology and purified on NGA medium. For long term storage, suspensions of each isolate were prepared in $30 \%$ glycerol solution and frozen at $-20^{\circ} \mathrm{C}$.

\section{IDENTIFICATION OF BACTERIA}

Gram reaction of bacterial isolates was determined by the rapid non staining method described by BucK (1982).

Thirty-five isolates selected on the basis of their origin and colony morphology were identified by the partial $16 \mathrm{~S}$ rRNA gene sequence analysis. Bacterial strains were grown in $5 \mathrm{ml}$ of Luria Broth (Difco) overnight at $27^{\circ} \mathrm{C}$. One $\mathrm{ml}$ of each culture was used for DNA extraction by using EZNA bacterial DNA kit (Omega bio-tech) following the protocols of the kit manufacturer for Gram positive or Gram negative bacteria.

The amplification was performed in $25 \mu$ l volume using $200 \mathrm{ng}$ DNA, 20 pmol of each primer fD 1 [ $\left(5^{\prime}-\right.$ AGAGTTTGATCCTGGCTCAG - 3') and rP1/rP2 (5' GGYTACCTTGTTACGACTT - 3'; Y=C/T)] (PIOUS and THYVALAPPIL, 2009), $50 \mu \mathrm{M}$ dNTPs and 0.5 units of Taq DNA polymerase (Invitrogen). Amplification cycle was the same as reported by PIOUS et al., (2008). PCR products were sequenced by Primm s.r.l. (Milano, Italy) by using the primer set involved in PCR reaction. Similarity of partial 16S rDNA nucleotide sequences with known sequences in the NCBI GenBanK database was determined by BLASTn (http://blast.ncbi.nlm.nih.gov/). Strains were identified at species level when they shared more than $97 \%$ identity with reference strains. Partial sequence data for the $16 \mathrm{~S}$ rRNA genes have been deposited in the EMBL/GenBank/DDBJ nucleotide sequence data libraries. Data for bacterial strains identified in this study have been deposited under accession numbers.

\section{ENZYME PRODUCTION BY BACTERIAL STRAINS}

Strains identified at species level were characterized for production of chitinase, lecithinase lipase and protease. The ability to degrade chitin was checked by streaking the four strains on M9 minimal medium amended with colloidal chitin (1\%) (SAMBROOK et al., 1989). Plates were incubated at $28^{\circ} \mathrm{C}$ for 96 hours. Strains that determined a clarification of the medium were considered chitinolytic. For the other tests, a $10^{8} \mathrm{cfu} / \mathrm{ml}$ suspension of each bacterial strain was prepared using fresh cultures grown on NGA for $24-48$ hours at $28^{\circ} \mathrm{C}$. Fifty $\mu$ of each bacterial suspension were placed on egg yolk agar (EYA) plates for lecithinase, LB agar plates amended with Tween $40(1 \%)$ for lipase and skim milk agar (SMA) plates for protease tests. Plates were incubated at $28^{\circ} \mathrm{C}$ and monitored at different times. Each test was repeated three times. An opaque halo around the macrocolonies, easily visible by transmitted light on EYA, indicated lecithinase production. Lipolytic activity was considered positive when the formation of a whitish halo around the macrocolonies was observed on LB agar. The formation of a transparent halo surrounding the macrocolonies on SMA indicated proteolytic activity.

\section{RESULTS}

Twenty and fifteen bacterial strains were selected on the basis of colony morphology from $R$. ferrugineus larvae and pupae respectively. Only one strain from larvae was Gram negative and was identified as Stenotrophomonas spp. since it shared only $96 \%$ identity with the reference strains. Nineteen strains were Gram positive including fifteen Bacillus spp., two Paenibacillus spp. and one Brevibacillus spp. One Brevibacillus parabrevis (TAKAGI et al., 1993) (98\% identity) and one Paenibacillus pabuli (NAKAMURA et al., 1984) (98\% identity) strains were correctly identified. Among the Bacillus spp., one strain was identified as B. thuringiensis Berliner, (SKERMAN et al., 1980) (99\% identity). (Fig. I, 1). The remaining Bacillus strains were not identified at species level by the analysis of $16 \mathrm{~S}$ gene sequence because the percentage identity with the sequence of reference strains was lower than $97 \%$.

Bacteria isolated from pupae were mostly Gram negative and belonged to the genera Alcaligenes, Morganella, Myroides, Providencia and Serratia. At species level one Providencia rettgeri (JACKSON et al., 1995) (99\% identity) and two Serratia marcescens Bizio (SKERMAN et al., 1980) (99\% identity) strains were identified. Only three isolates, out of fifteen, were Gram positive and were all affiliated to Bacillus genus, the strain E2 was identified as B. subtilis subsp. subtilis. (Fig. I, 2). EMBL/GenBank/DDBJ accession numbers for the strains identified at species level were: A1, KX002005; E2, KX002006; B4, KX002007; B3, KX002008; D4, KX002009; C3, KX002010; D3, KX002011.

$S$. marcescens was the only chitinolytic species and was able to produce proteases, lecithinase (only strain D3) and lipases too. $B$. thuringiensis produced protease, lecithinase and lipase while B. subtilis subsp. subtilis showed proteolytic activity only. $B$. parabrevis produced lecithinase and lipase while P. pabuli was only lipolytic. $P$. rettgerii did not show any of the tested enzymatic activity (Table 1)

\section{DISCUSSION}

The search for natural enemies is a fundamental step to develop an IPM strategy against $R$. ferrugineus, a destructive parasite of palm trees, given the lack of an effective control method environmental friendly and safe for human health. The potential of entompathogenic bacteria has been investigated since from the last century when the efficacy of some Bacillus species in controlling dangerous pests was discovered (SANCHIS and BouRGUET, 2008; RUIU et al., 2013).

In the present study, bacterial strains isolated from larvae and pupae of $R$. ferrugineus were identified and characterized for their enzymatic activity. Four strains may be considered putative antagonists of $R$. ferrugineus while the remaining strains represent a part of the natural microflora normally associated to the insect.

Bacteria associated with larvae were mostly Gram positive spore-forming bacteria, with the majority of strains belonging to Bacillus genus. Strain A1 was identified as $B$. thuringiensis, one of the most effective entomopathogenic bacterial species. This species is able to produce parasporal bodies (Crystals) containing specific endotoxins (Cry proteins) acting by ingestion, that are the active molecules of several commercial insecticides. $B$. thuringiensis strain A1 was able to produce lecithinase, lipase and protease in vitro, three lytic enzymes that could be involved in degradative process of host cells. The presence of Bacillus species in the dead specimens of 


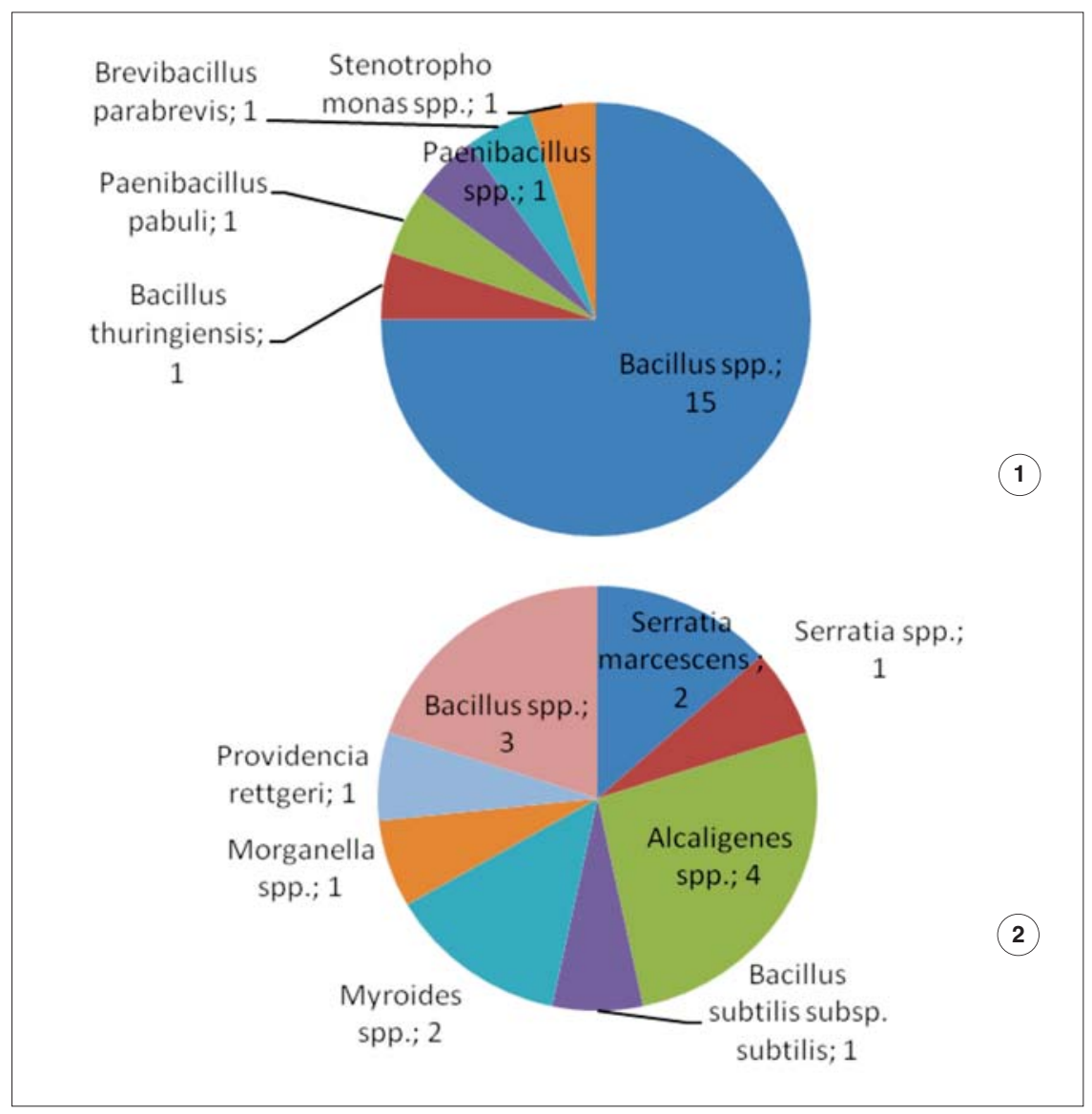

Fig. I - Distribution of bacteria isolated from larvae (1) and pupae (2) of $R$. ferrugineus on the basis of their genera or species affiliation.

Table 1 - Production of lytic enzyme by the bacterial strains isolated from larvae and pupae of $R$. ferrugineus (size of halo surrounding the colony: $+:<1 \mathrm{~cm} ;++:>1 \mathrm{~cm})$.

$\mathrm{B}=$ Bacillus $; \mathrm{Br}=$ Brevibacillus $; \mathrm{P}=$ Paenibacillus $; \mathrm{Pr}=$ Providencia $; \mathrm{S}=$ Serratia .

\begin{tabular}{llccccc}
\hline \hline & Origin & Gram & Chitinase & Lecithinase & Lipase & Protease \\
\hline B. thuringiensis 1 & larvae & + & - & ++ & + & ++ \\
P. pabuli B3 & larvae & + & - & - & + & - \\
Br. parabrevis B4 & larvae & + & - & + & + & - \\
S. marcescens C3 & pupae & - & + & - & + & + \\
S. marcescens D3 & pupae & - & ++ & + & ++ & ++ \\
Pr. rettgeri D4 & pupae & - & - & - & - & - \\
B. subtilis. subsp. subtilis E2 & pupae & + & - & - & - & +
\end{tabular}

larvae showed that in some cases the antimicrobial defense compounds detected in the cuticola of $R$. ferrugineus larvae that inhibit Bacillus spp. growth, may be overcome (MAzzA et al., 2011). Evidences derived from literature reported that $B$. thuringiensis activity is low against $R$. ferrugineus immature stages notwithstanding midgut damages and feeding inhibition (DEMBILIO and JACAS, 2013) while $B$. thuringiensis var. kurstaki activity against $R$. ferrugineus larvae is high (MAHMOUd et al., 2011). Strain B4 of B. parabrevis isolated from larvae was able to produce lecithinase and lipase in vitro. This species has never been reported as an enthompathogen, but it was previously isolated from adults of the Coleoptera Lasioderma serricorne, (Fabricius) (YAMAN et al., 2008) where probably it is able to establish a symbiotic interaction with the host. The species Brevibacillus laterosporus is able to develop mutualistic (with Apis mellifera) or pathogenic (with Musca domestica) interactions with diverse insect species, probably as the result of a coevolutionary process (MARCHE et al., 2016). In the light of this findings, the kind of interaction occurring between $R$. ferrugineus larvae and $B$. parabrevis may deserve further analysis.

Bacterial microflora of $R$. ferrugineus pupae showed a strong diversity. Five different Gram negative and one Gram positive genera of bacteria were identified. Strain E2 was identified as B. subtilis subsp. subtilis (SKERMAN et al., 1980) and was able to produce protease. For some 
spore-forming isolates belonging to the Bacillaceae family, the $16 \mathrm{~S}$ sequence similarity was less than $97 \%$ so that they could not be affiliated to any species. Given the complexity and variability of this group of bacteria, a multiphasic approach is often needed to precisely identify Bacillus strains (SCHMIDT et al., 2011). Strains D4 of $P$. rettgeri and $\mathrm{C} 3$ and $\mathrm{D} 3$ of $S$. marcescens are the most interesting bacteria isolated from pupae. $P$. rettgerii is an insect pathogenic bacterium that has been found associated to Galleria mellonella L. larvae and Drosophila melanogaster Meigen, 1830; the bacterium may be highly lethal to these hosts (JACKSON et al., 1995; GALAC and LAZZARO, 2011). S. marcescens is the most frequently reported entomopathogen for a wide of invertebrate hosts (included Coleoptera) where it is able to colonize the gut and later pass to the hemocoel causing the destruction of hemocites and internal organs (SANCHEZ-CONTRERAS and VLISIDOU, 2008). This mechanism seems to be very common among the entomopathogenic non spore-forming bacteria (MAHAR et al., 2005) that do not elicit the systemic immune response of the host. Bacteria belonging to Bacillus and Serratia genera have been already reported in association to $R$. ferrugineus larvae or pupae (BUTERA et al., 2012; MAHMOUD et al., 2001; SALAMA et al., 2004). To our knowledge this is the first time that the entomopathogenic bacterial species Providencia rettgeri was found as component of the microflora associated to this insect.

Many bacteria pathogens to insects are active producers of secondary metabolites toxic to insects or other kind of organisms, that can be used as novel molecules for controlling both plant pathogens and pests (BODE, 2009). The extraction and identification of secondary metabolites produced by the entomopathogenic bacteria isolated in this study as well as the in vivo activity of bacterial cells against $R$. ferrugineus needs to be evaluated.

\section{ACKNOWLEDGMENTS}

The research was supported by a grant from Ministry of Agricultural, Food and Forestry (MiPAAF) national project "Protection of ornamental and indigenous palms from the biological invasion of the Red Palm Weevil" PROPALMA” (D.M. 25618/7301/11, 2012/12/01)

\section{REFERENCES}

Banerjee A., Dangar T.K., 1995 - Pseudomonas aeruginosa, a facultative pathogen of red palm weevil, Rhynchophorus ferrugineus. - World J. Microbiol. Biotechnol.,11: 618-620.

BERLINER E., 1911 - Ârber die schlafsucht der mehlmottenraupe. - Z. Gesamte Getreidewes., 3: 63. (Ita).

BodE H.B., 2009 - Enthomopathogenic bacteria as a source of secondary metabolites. - Curr. Op. Chem. Biol., 13: 224-230.

BUCK J.D., 1982 - Nonstaining (KOH) method for determination of Gram reactions of marine bacteria. Appl. Environ. Microbiol., 44: 992-993.

Butera G., Ferraro C., Colazza S., Alonzo G., Quatrini P., 2012 - The culturable bacterial community of frass produced by larvae of Rhynchophorus ferrugineus Olivier (Coleoptera Curculionidae) in the Canary island date palm. - Lett. Appl. Microbiol., 54: 530-536

Cito A. Mazza G., Strangi A., Benvenuti C., Barzanti
G.P., Dreassi E., Turchetti T., Francardi V., Roversi P.F., 2014 - Characterization and comparison of Metarhizium strains isolated from Rhynchophorus ferrugineus. - FEMS Microbiol. Lett., 108-115.

Dembilio O., Jacas J.A., 2013 - Biological control of Rhynchophorus ferrugineus. AFPP, Palm Pest Mediterranean conference, Nice-16-17 and 18 January 2013. http://www.fredon-corse.com/standalone/3/ D69ANkjtflQHq48559kh4bk0.pdf

Francardi V., Benvenuti C., Roversi P. F., Rumine P., BARZANTI G.P., 2012 - Entomopathogenicity of Beauveria bassiana (Bals.) Vuill. and Metarhizium anisopliae (Metsch.) Sorokin isolated from different sources in the control of Rhynchophorus ferrugineus (Olivier) (Coleoptera Curculionidae). - Redia, XCV: 4955.

Francardi V., Benvenuti C., Barzanti G.P., Roversi P. F., 2013a - Autocontamination trap with entomopathogenic fungi: a possible strategy in the control of Rhynchophorus ferrugineus (Olivier) (Coleoptera Curculionidae). - Redia, XCVI: 57-67.

Francardi V., Benvenuti C., Barzanti G.P., Roversi P. F., 2013 b - Controllo microbiologico di Rhynchophorus ferrugineus (Olivier) (Coleoptera Curculionidae) mediante impiego di una trappola "attract, infect and release”. - Atti Acc. Naz. Ital. Entomol., LXI: 205-209.

Francardi V. , Benvenuti C., Mazza G., Barzanti G.P., Carletti B., Cito A., Longo S., Raio A., Gori M., Nannelli R., De Silva J., Roversi P. F., 2014 Organismi Associati a Rhynchophorus Ferrugineus (Olivier) In Sicilia. XXIV Cong. Naz. Entomol. Orosei 914 Giugno: 26.

GalaC M.R., LAZZARo B.P., 2011 - Comparative pathology of bacteria in the genus Providencia to a natural host, Drosophila melanogaster. - Micr. Inf., XX: 673-683.

Jackson T.J., Wang H., Nugent M.J., Griffin C.T., BuRNELl A.M., DowDS B.C.A., 1995 - Isolation of insect pathogenic bacteria, Providencia rettgeri, from Heterorhabditis spp. - J. Appl. Bacteriol., 78: 237-244.

Marche G., Mura M.E., RuIU L., 2016 - BREVIBACILLUS LATEROSPORUS inside the insect body: Beneficial resident or pathogenic outsider? - J. Inv. Pathol., 137: 58-61.

Mahar A.N., Munir M., Gowen S.R., Hague N.G.M., 2005 - Role of entomopathogenic bacteria, Photorabdus luminescens and its toxic secretions against Galleria mellonella larvae. - J. Entomol., 2: 69-76.

Mazza G., Francardi V., Longo S., Nannelli R., Tarasco E., Cervo R., Benvenuti C., Roversi P.F., 2013 - Controllo biologico del Punteruolo rosso delle palme Rhynchophorus Ferrugineus (Olivier). - Atti Acc. Naz. Ital. Entomol., LXI: 211-217.

Mazza G., Arizza V., Baracchi D., Barzanti G. P., Benvenuti C., Francardi V., Frandi A., Gherardi F., Longo S., Manachini B., Perito B., Rumine P., Schillaci D., Turillazzi S., Cervo R., 2011 Antimicrobial Activity of The Red Palm Weevil Rhynchophorus ferrugineus. - Bull. Insectol., 64 (1): 3341.

Mazza G., Francardi V., Simoni S., Benvenuti C., Cervo R., Faleiro J.R., Llacer E., Longo S., Nannelli R., TARAsco E., Roversi P.F., 2014 - An overview on the natural enemies of Rhynchophorous palm weevils, with focus on R. ferrugineus. - Biol. Control, 77: 83-92.

NAKAMURA L.K., 1984 - Bacillus amylolyticus $s p$. nov., nom. rev., Bacillus lautus sp. nov., nom. rev., Bacillus pabuli sp. nov., nom. rev., and Bacillus validus sp. nov., nom. rev. - Int. J. Syst. Bacteriol., 34:224-226. 
Mahmoud M. M. A., Ismail I. M., Amin M. K., FAyed A. H., Mostafa S. A. 2011 - Isolation and identification of novel local isolates of Bacillus thuringiensis active against Red Palm Weevil (RPW). - Egypt. J. Genet. Cytol., 40: 337-350.

Pious T., Ganiga K. S., Pulak K.R., Prakash P., 2008 Identification of culturable and originally non-culturable endophytic bacteria isolated from shoot tip cultures of banana cv. Grand Naine. - Plant Cell, Tissue Org. Cult. 93:55-63.

Pious T., ThyvalappiL A.S., 2009 - Endophytic bacteria associated with growing shoot tips of banana (Musa spp.) cv. Grand Naine and the affinity of endophytes to the host. - Microbial Ecol. 58 : 952-964.

Ruiu L., Satta A., Floris I., 2013 - Emerging entomopathogenic bacteria for insect pest management. Bull. Insect. 66: 181-186.

Salama H.S., Foma M.S., El-Bendary M.A., AbdelRAZEK A., 2004 - Infection of red palm weevil, Rhynchophorus ferrugineus, by spore-forming bacilli indigenous to its natural habitat in Egypt. - J. Pest Sci., 77: 27-31.

SAmbrook J., Fritsch E.F., Maniatis T., 1989 - Molecular cloning: a laboratory manual. Cold Spring Harbor Laboratory, Cold Spring Harbor, New York, 253 pp.
SANCHEZ-CONTRERAS M., VLISIDOU I., 2008 - The diversity of insect-bacteria interactions and its applications for disease control. - Biotechnol. Gen. Eng. Rev., 25: 203-244.

SANCHIS V., BOURGUET D., 2008 - Bacillus thuringiensis: application in agriculture and insect resistance management. A review. - Agron. Sustain. Dev., 28: 11-20.

Schmidt T.R., ScotT II E.J., Dyer D.W., 2011 - Wholegenome phylogenies of the family Bacillaceae and expansion of the sigma factor gene family in the Bacillus cereus species-group. - BMC Genomics, 12: 430-445.

Skerman V.B.D., Mcgowan V., Sneath' P.H.A., 1980 Approved Lists of Bacterial Names. - Int. J. Syst. Evol. Microbiol., 30: 225-420

Takagi, H., Shida, O., Kadowaki, K., Komagata, K., UDAKA, S., 1993 - Characterization of Bacillus brevis with descriptions of Bacillus migulanus sp. nov., Bacillus choshinensis sp. nov., Bacillus parabrevis $s p$. nov., and Bacillus galactophilus $s p$. nov. - Int. J. Syst. Bacteriol., 43: 221-231.

Yaman M., Aslan I., , Görmez A., Ertürk Ö., 2008 Bacterial flora of Lasioderma serricorne (F.) (Coleoptera: Anobiidae) from several tobacco stores in Turkey. IOBC/wprs Bull., 40: 49-52. 
